B. Shirinov, PhD, Senior Lecturer, Azerbaijan University of Architecture and Construction, Baku, Azerbaijan ORCID ID: 0000-0003-4872-4035

\title{
THE ROLE OF LOGISTICS ANALYSIS METHODS IN THE ENTERPRISE RESOURCE MANAGEMENT SYSTEM
}

\author{
Б. Г. Шірінов, \\ доктор філософії з економіки, старший викАадач, \\ Азербайджанський Архітектурно-Будівельний Університет, м. Баку, Азербайджанська Республіка
}

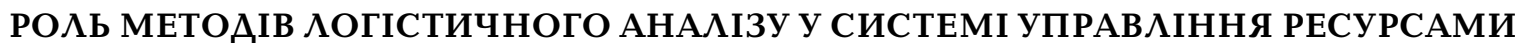 \\ ПІАПРИЕМСТВ
}

The article discusses the role of logistic analysis methods in the enterprise resource management system. The author refers to modern problems of resource management, the main indicators used in the management of inventories, the methods used in the management of inventories of enterprises, the main indicators used to assess the effectiveness of the chosen policy in inventory management, etc. issues are researched. The goals of the individual units of the enterprise often contradict each other. The goals of various divisions of the enterprise for the use of resources are contradictory and the solution of this problem is one of the main tasks of logistic resource management. The author considers that the reserve policy is somehow determined by a significant influence on the structure of the enterprise, concessions between risks and costs, liquidity and turnover are determined.

The second path is more difficult because management requires skills in resource management and management accounting. A sequence of simplest steps along the way is recommended. In most cases, resource management in a material nomenclature is so extensive that it is simply impossible to analyze and modernize every situation in the nomenclature in detail. To simplify this problem, the article conducts an AVS-analysis of the entire range of materials and divides the resources into three groups. Here, indicates $A$ - a high value of volume, $V$-moderate value of volume and $S$ - low value of volume. When the A VSanalysis is combined with the $X Y Z$ analysis, the enterprise effectively manages the acquisition of materials. The article substantiates and proves the method of conducting a comprehensive analysis of AVS and XYZ. XYZ-analysis allows the enterprise to carry out the classification of these resources together and depends on the accuracy of forecasting changes in their needs. XYZ - grouping of resources in the analysis is carried out in the order of increasing coefficient of variation. The author notes that the proper optimization of material resources allows you to minimize costs, increase quality and efficiency of production, and ultimately increase the profitability of capital.

У Статті розгАядається роль методів Аогістичного аналізу у Системі управАіння ресурсами підприємСтва. Автор звертається, до сучасних Проблем управління ресурсами, основним показникам, що викориСтовуються в Управлінні матеріально-виробничими запасами, методам, що використовуютьСя в УПравлінні матеріально-технічними запасами підприємСтв, основним показникам, що використовуютьСЯ ААЯ оцінки ефективності обраної політики в управлінні запасами і т.А. Цілі окремих підрозділів підприємСтва часто суперечать один одному. Цілі різних підрозділів підприсмства з використання ресурсів суперечливі та вирішення цієї проблеми є одним з основних завдань Аогістичного управління ресурсами. Автор вважає, що резервна політика так чи інакше визначається значним впливом на структуру підприємСтва, визначаються поступки між ризиками та витратами, ліквідністю та оборотністю. 
Аругий шлях СкАадніший, томущодля управління потрібні навички управління ресурсами та управлінського обліку. Рекомендується послідовність найпростіших кроків на цьому шляху. Найчастіше управління ресурсами в номенкАатурі матеріалів настільки широко, що неможливо детально проаналізувати $i$ модернізувати кожну ситуацію в номенкАатурі. Щоб спростити це завдання, У статті ресурси поділено на три групи та проводиться AVS-аналіз всього спектра матеріалів. A-позначає високе значення об'єму, V-помірне значення об'єму та $S$-низьке значення об'єму. Коли аналіз AVS поєднується з аналізом $X Y Z$, підприємство ефективно управляє придбанням матеріалів. УСтатті обгрунтовано методику проведення комплексного аналізу AVS та XYZ. XYZ-аналіз дозволяє ПіАприємству проводити кАасифікацію цих ресурсів разом та залежить від точності прогнозу зміни їх потреб. XYZ - угруповання ресурсів У аналізі зАійснюеться У порядку збільшення коеріцієнта варіації.

Автор зазначає, що правильна оптимізація матеріальних ресурсів дозволяє мінімізувати витрати, підвищити якість та ефективність виробництва, і в результаті підвищити рентабельність капіталу.

Key words: logistics, reserve, information, receivables, profitability, order, metbod.

Ключові слова: логістика, резерви, інформачія, дебіторська заборгованість, рентабельність, порядок, метод.

\section{INTRODUCTION}

Defining logistics as the theory and practice of managing material and information and financial flows associated with it, a joint consideration as a process can ensure the activities of the enterprise with maximum synrgetic efficiency. In the literature today, it is most common to obtain flows in binary: finance in combination with information, material or information, almost financial flow management is the least studied area in logistics.

In any logistics system, material and financial flows in time and space are closely interconnected with information flows and directly affect the production, operational and financial result, as well as the structure and volume of working capital of the enterprise. The entry of raw materials and semi-finished products from suppliers in the type of material flow "accumulates" in the warehouse of the enterprise as a production reserve, increasing the corresponding type of circulating assets. The time of stay of raw materials in the Reserve increases the volume of the production cycle, while the conditions for payment of supplies affect the sequence of financial results [3].

Modern problems of resource management.

The availability of reserves of raw materials in the warehouse ensures the continuity of the production process, and the stock of finished products makes it possible to promptly satisfy the existing demand, however, it ensures the organizational-economic stability of the enterprise. On the other hand, inventories and receivables form the main component of the enterprise's turnover assets, therefore, changes in their value, structure and trends directly affect the financial stability of the enterprise.

In April 2002, the U.S. supply chain Council on logistics objectives management issues (Supply Chain Council) approved a new version of a computer model to assess the efficient performance of logistics objectives. One of the functions of optimizing this model at the first level is the efficiency of asset management with the following indicators: speed of money circulation for logistics, volume of reserves (days), circulation of working capital [5].

The problem of resource management worries practically every enterprise today. It is advisable for managers to switch from net empirical solutions to the most objective criteria on the volume of receipt of raw materials, depending on the availability of natural cash in cash.
In the investment of a system of effective management of inventories, the enterprise needs, first of all, stability. One of them is the positive aspects of the existence of reserves: ensuring a large degree of reliability in work, expressed in the continuity of the production process, or ensuring the demand of buyers, the other-the costs of maintaining negative reserves, the exclusion of capital invested in reserves from circulation. Thus, the main units of the enterprise form their attitude to the formation of reserves in different ways. A priority is the positive aspects of the availability of reserves for the production department, the purchase and sale service. Financial and plan services seek to reduce reserves to a minimum level of opportunity, since important for them is the reduction in total costs and the acceleration of the circulation of current assets. The contradictory goals of various divisions of the enterprise in relation to inventories create a dispute, the regulation of which is one of the main tasks of logistic management of inventories [4].

There are two principal directions of solving the problem of dispute of goals. The reserves policy is determined by one or another strong impact on the structure of the enterprise, discounts between risks and costs or liquidity and circulation are determined.

The second direction is the most difficult, because it requires strategic thinking from management, habits in matters of resource management and accounting of management invested. The sequence of the simplest steps of movement in this direction is recommended:

- The first step-determination of the value of reserves, their nomenclature and quantitative characteristics (volume, temporary parameters, information on their location.

- Second step-US analysis and detection of major reserves of Category A, less important category $V$ and secondary significant category $\mathrm{S}$;

- The third step-the registration of methods and techniques used by the enterprise in the management of inventories. Selection of criteria for assessing the result and organization of accounting in the current system of resource management. This allows you to get all the necessary information for this purpose;

-The fourth step-comparison of existing methods and methods of resource management with the required ones; 
- The fifth step-the transition from the state of" how to have "to the state of" how to be". Development of a new one or improving the functioning system of resource management.

The main indicators used in the management of inventories.

In the quality of the basic criteria for assessing the chosen policy in the management of inventories, generalized criteria, as well as their various combinations, can be used. Thus, the most important is not the possible criteria chosen by the enterprise (company), but the actual existence of these criteria. However, constant observation of such indicators allows us to make an idea of the correctness of focusing on creating an effective system of managing resources. Based on the selected criteria, the enterprise must find the optimal fit for itself between the usefulness of the level of costs and selection of reserves [7].

The main indicators used to assess the effectiveness of the selected policies of resource management are:

Indicators characterizing the profitability of the activities of enterprises (companies) using various methods of resource management.

Profitability of assets (AR) is defined as the output of two indicators during the calculation period: profitability of sales and turnover of assets during the period. The presence of excess reserves leads to an increase in the volume of assets, thus, a decrease in their value. For inventories, it is necessary to determine the optimal volume of investments, so that it is advisable to increase the turnover of assets so as not to lead to a decrease in the profitability of assets due to a decrease in sales.For him, it is necessary to determine the density of relations between all indicators included in the formula for calculating the profitability of assets. Knowing the structure of assets, that is, the size of the reserves of assets at the enterprise can be calculated - how much assets can be reduced in a certain decrease in inventories. Then the effect of this decrease on the turnover of assets is determined. After that, it is determined how much the cost of work changes, which means that profit is determined at the expense of a decrease in reserves in this volume. In this case, the cost includes not only the costs of maintaining reserves, but also the costs of withdrawing capital from the economic cycle. Costs can be calculated in a broad form, multiplying the days of the duration of one circulation at the average daily rate of a bank loan.

Indicators related to the characterization of cash flows using transactions on the acquisition and realization of goods.

The amount of net discounted cash flow is equal to the difference between the discounted part of the funds, which is directed to the funds received without implementation during the settlement period and the purchase of goods. The discount rate can be used as: rate on alternative investment of funds, for example, short-term financial investments and other business;profitability of specific funds of the Enterprise (Company); rate of equal value of credit resources, necessary to fill the shortage of working capital;rate equal to the inflation index [2].

Indicators based on the search for the optimal size of the order, based on the ratio of the cost of fulfilling the order and the cost of maintaining inventories.

Methods used in the management of inventories of enterprises.

In the XIX century, Vilfredo Pareto in his research on the distribution of material wealth in Milan found that $20 \%$
A- low amount of expenses

V- Optimal volume of order
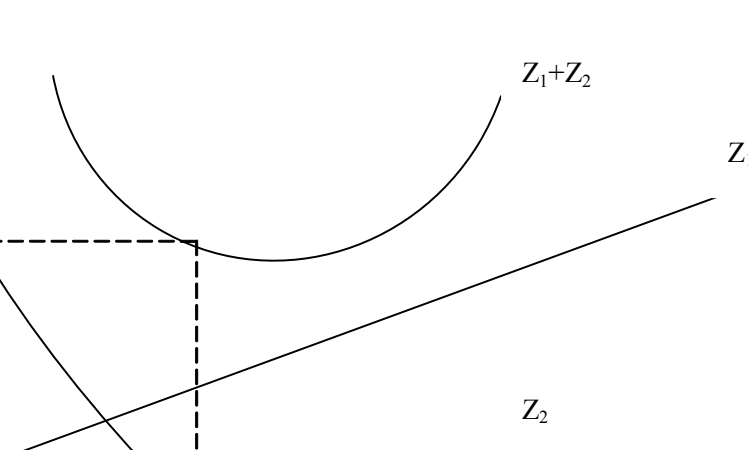

The volume of the order

$\mathrm{H}$ of people control $80 \%$ of all material wealth. Pareto began to apply this rule in other areas. As a result, this approach received the name Pareto Principle or AVS method [6].

The large volume of orders (thus, their quantity is small) reduces the cost of fulfilling orders (Z2), but increases the cost of maintaining inventories. (Z1). It is impossible to calculate this dependence due to the accumulation of additional enterprise information. The result of this work entails the identification of two indicators: the costs of fulfilling the order and the cost of maintaining the reserve unit. It is necessary to increase the volume of the order until such a time that the decrease in the costs of the existing order exceeds the increase in storage costs, that is, the optimal volume of the order is concentrated in the minimum amount of costs (Figure 1.). When working with an Optimal order model, it should be borne in mind that the use of any analytical methods not only provides benefits, but also requires additional costs, which include the organization of additional jobs, the involvement of the highest staff, the inclusion of additional methods for collecting and processing information, distraction of time for higher management personnel, obtaining software, etc.the desire to achieve real success from the planned analytical work should be observed with cost estimation.

In this regard, the implementation of the order for a limited amount of the most significant in the value ratio of the optimal volume, level of Service, withdrawal of capital resources from economic turnover and other indicators of assortment positions is purposeful, t.to detect it, structuring inventories should be carried out with the help of known typified methods of logistics analysis techniques: AVS and XYZ.

Any system of reserves at a certain moment should indicate the placement of the order in this or that material, as well as determine the volume of the order. In most cases, the management of stocks in the nomenclature of materials is so wide that a detailed analysis and modernization of each state of the nomenclature is simply unrealistic. To simplify this problem, an AVS-analysis of the entire nomenclature of materials is carried out, as a result of which the resource is supposed to be divided into three groups. High value of 


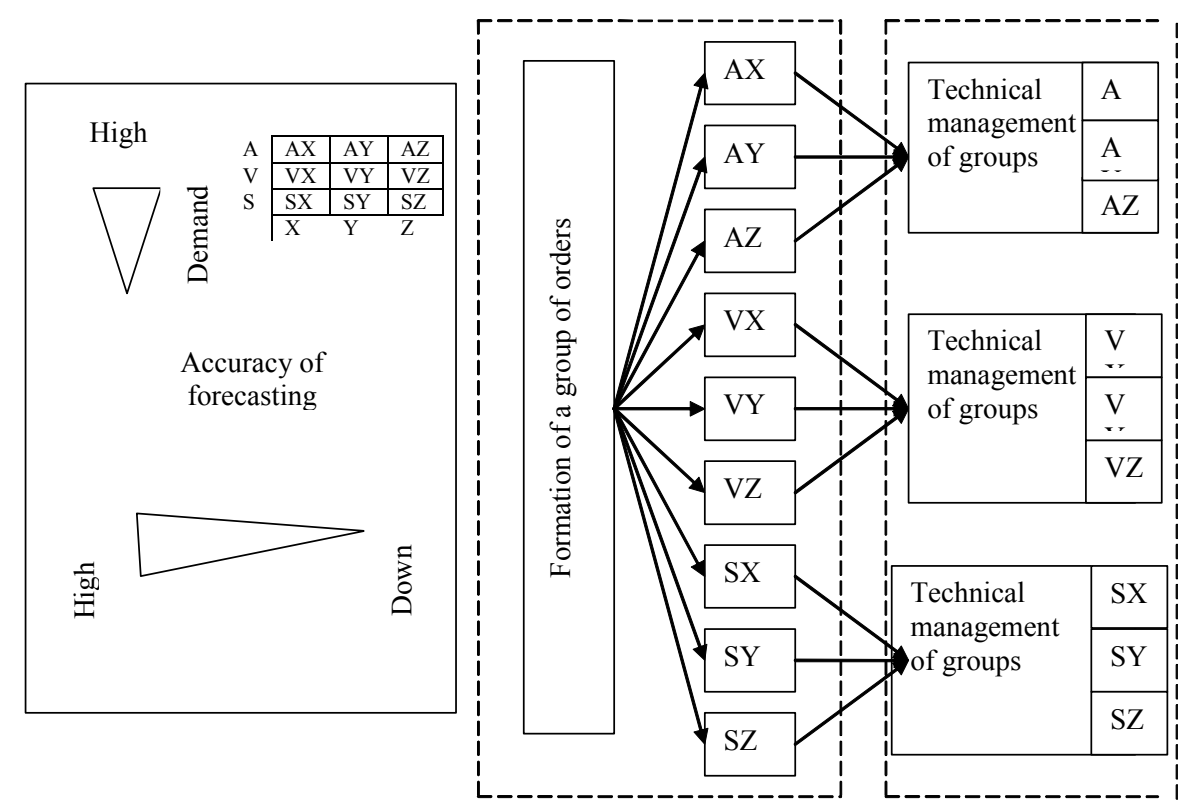

Fig. 2. Comprehensive analysis of AVS-XYZ

volume (A), moderate value (V) of volume and low value (S) of volume. Cost volume is a relatively cheap product, but buying cheap in large volumes can be the most important, compared to a small amount of expensive. AVSanalysis is gaining popularity among the heads of companies of our country. But the greatest efficiency gives when it is a combination with XYZ-analysis.

$\mathrm{XYZ}$-analysis allows the enterprise to carry out together with the classification of those resources, for example, stocks of raw materials and materials, but it depends on the nature of their consumption and the accuracy of forecasting the change in demand for them. Grouping of resources in the conduct of XYZ-analysis is carried out in the order of increasing the variation coefficient.

Instead of the result of the analysis of XYZ in the data of the analysis of AVS, we get 9 groups of reserves, for each of which the manager of the enterprise (company) must work his own management technique (Figure 2).

Category $X$ refers to resources with a coefficient of variation of less than $10 \%$. They are characterized by stable quantity of consumption, uncertain change of their consumption and high accuracy of forecast.

Category $\mathrm{Y}$ - the demand for these resources is characterized by known trends (e.g., seasonal fluctuations) and average forecasting opportunities, the coefficient of variation of which varies from $10 \%$ to $25 \%$.

Resources belonging to category $\mathrm{Z}$ are consumed on an irregular basis, the exact prediction of their demand is not so much, the coefficient of variation is more than $25 \%$. Resources belonging to category $\mathrm{Z}$ are consumed on an irregular basis, the exact prediction of their demand is not so much, the coefficient of variation is more than $25 \%$.

\section{CONCLUSIONS}

The results of the AVS-XYZ complex analysis are necessary for the development of the procedure for allocating the most important resources of the enterprise and determining the priorities in the allocation of reserves and determining the volume of orders. Policy development in the sphere of reserves for these groups requires accurate development of the acquisition management system at the enterprise. The result of conducting a complex analysis of AVS - XYZ is necessary for the development of the procedure for allocating the most important reserves of the enterprise and determining priorities in placing reserves based on it and determining the volume of orders. The correct implementation of resource optimization allows you to minimize costs, improve the quality and efficiency of production, thereby increasing the profitability of capital in operation.
References:

1. Aliyev, R.M., Novruzov, N.A. and Mammadov, M.A. (2003), Investment financing and lending, Baku, Azerbaijan.

2. Aliyev, R.B. (2003), Theory of economic analysis, Baku, Azerbaijan.

3. Huseynov, T.A (2009), Investments in Azerbaijan, Science, Baku, Azerbaijan.

4. Mehdiyev, I.A. and Shiraliyev, V.M. (2005), Economics of construction. Textbook, Baku, Azerbaijan.

5. Mammadov, M. A. (2008), Program-oriented management in the transition economy, Baku, Azerbaijan.

6. Mammadov, M.A. and Shirinov, B.H. (2013), "Alternative strategy for identifying and financing the effective need for working capital", Institute of Economics of the Azerbaijan National Academy of Sciences, Scientific works, vol.1, pp 156-161.

7. Shirinov, B.H. (2017), "Methods of normalization of working capital in construction enterprises", Azerbaijan University of Architecture and Construction ScientificPractical Journal of Construction Economics and Management, vol. 3 .

Стаття надіймла до редакиії 27.11.2021 p.

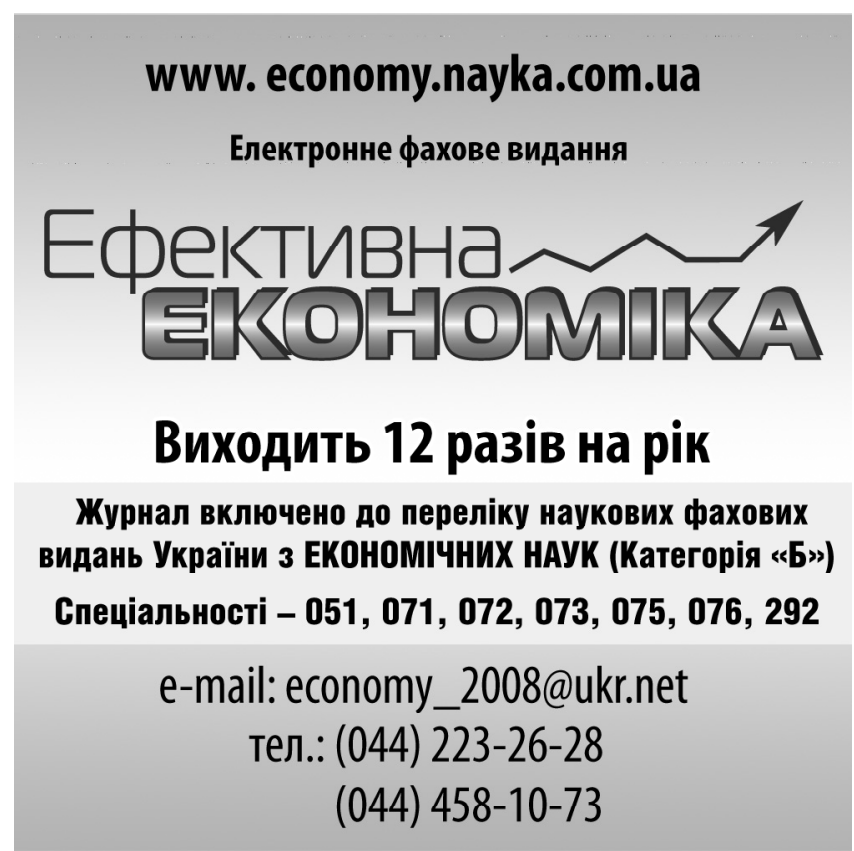

